\title{
Basic Skills of Men Garuda Basketball Athlete
}

\author{
Ronni Yenes ${ }^{1 *}$ and Ryan Gutrianto ${ }^{2}$ \\ ${ }^{1,2}$ Dep. of Coaching, Faculty of Sport Science, Universitas Negeri Padang, Padang, Indonesia \\ *Corresponding author. Email: ronniyenes@fik.unp.ac.id
}

\begin{abstract}
The purpose of this study is to determine the passing, dribbling andshooting skills possessed by Padang Basketball athletes. This type of research is descriptive research. The sample in this study were all Putra Garuda Basketball athletes in the age group of 23 . The instrument used in this research arepassing, dribbling, and shooting basketball skill test. Data analysis in this study used descriptive analysis. The results of this study are the average passing skills of the Putra Garuda Basketball athletes were in the moderate category with a percentage of $46.67 \%$ ( 7 people), which was in the excellent category $6.67 \%$ (1 person), in the good category $13.33 \%$ (2 people) in the category of $33.33 \%$ less (5 people) . The dribbling ability possessed by Putra Garuda Basketball athletes is in the sufficient and less categories with a percentage of $53.33 \%$ ( 8 people), in the good category with a percentage of $46.67 \%$ ( 7 people). The shooting ability possessed by Putra Garuda basketball athletes is in the sufficient and less category with the percentage of $80 \%$ (12 people), in the good category with a percentage of $20 \%$ (3 people).
\end{abstract}

Keywords: passingskills, dribblingskills, shootingskills, basketball

\section{INTRODUCTION}

The development of science and technology at the present time has brought progress in all sectors especially basketball. Basketball is one of the favorite sports games because it can be done by children, teenagers, and also adults.

In Indonesia, the basketball game develops quickly. Its development began after the proclamation of independence, starting from the area around Semarang. Before independence, this game was played in schools of Tionghoa descent but did not involve the interests of the whole community. So that in 1948 raced for the first basketball game in PON I in Solo. At the beginning of Indonesian independence, the nation still faces threats from the Dutch colonial successfully 1 robs some part of the Unitary State Republic of Indonesia which has been declared.

According to Fardi (1999) says that "on 23 October 1951, the organization established PERBASI (entire Indonesian Basketball Association) and then in 1955 the union of basketball throughout the first Indonesian turned into a basketball unity throughout Indonesia. For showing performance, then PERBASI holdsJava conference in Bandung, where the conference results that PERBASI make himself as the parent organization of basketball in Indonesia.

Until now, PERBASI still shows its performance. Where the development of Indonesian basketball is quite promising at national and international levels. This can be seen from the existence of prestigious competencies that are rolling at the national level such as, LIBAMA or Student Basketball League, IBL or Indonesia Basketball League, and many more competitions that are rolling in Indonesia at this time. Not only at the level of professional A basketball competition was held, at the student level however still widely held basketball competitions. So that at present the basketball coaches are competing to train and educate their athletes so that the athletes become achievers and become champions in the competitions they participate in.

Basketball games is a game that uses a lot of movement skills. So if a player has good movement skills, the movements he does will look beautiful. This is inseparable from the basic technique of playing basketball. The basic techniques that must be possessed by the game of basketball include footwork, Shooting, passing, catch, dribble, movement with the ball, movement without the ball, and the last movement. This is in accordance with the opinion Wissel (2000: 2) says that the technique of the basic game of basketball includes footwork, Shooting, passing, catch, train with, movement with the ball, movement without the ball, and the movement survive. From all the movements above, it can be arranged to become a series of movements in the basketball game.

The goal of the basketball game is to score as many points as possible and keep our ring from being broken. To be able to score points and defend the ring 
from the opponent's attack, of course, every basketball player must have the basic techniques of playing basketball properly and correctly. In addition, if every player has a good basic technique, then the stability of the team's game will be well maintained. So it can be concluded that the mastery of the basic technique of playing basketball cannot be underestimated by every basketball player.

Garuda basketball club is one of the basketball clubs in the city of Padang, which until now has remained active in carrying out coaching activities for basketball athletes from an early age, teenagers, even to adult athletes. Achievements achieved by the Padang Garuda basketball club have decreased from year to year, this can be seen from the results of the championships that he participated in the last few years. In 2017 the Garuda basketball club won only the second place after being defeated by FIK UNP alumni in the final round. In 2018 Garuda basketball club won only the third place after being defeated again by FIK UNP alumni in the semi-final.

Furthermore, based on observations by researchers in the field, during the match, the Garuda basketball club often fails to carry out attacks. Players often lose the ball when making attacks, dribbling and passing that they do easily intercepted by opposing players. Besides shooting they do often fail. So the Garuda basketball team often loses during matches.

Based on the phenomena that have been stated above, of course, there are many factors that affect the performance of Garuda basketball. One factor is the physical condition of the athlete. In basketball, physical condition is the main factor influencing the appearance of each team when competing. This is because the basketball game is a sport that has speed power endurance criteria. This can be seen in many basketball games there are movements in running and jumping using speed. So that it can be said that a good athlete's physical condition is an important indicator that must be possessed by every basketball athlete.

The next factor is the athlete's mentality during the match. Mental factors are one of the many factors that affect athletes' achievements, especially in basketball. When the intensity of the game goes high, the mentality of every athlete is an important factor that determines who will win in a match. Next is the basic technique (fundamental skill) possessed by all athletes, basketball game is a team sport that is carried out by 5 players. So it takes good techniques possessed by all athletes so that a team can play well. In addition, a proverb of basketball said that basketball is a habit which means playing basketball is a habit. So if an athlete has been trained with the right technique, then the athlete will definitely use the correct technique during the match.

Another factor influencing the performance of the Garuda basketball club is the competency of the coach he has. The coach is a designer for a team, the coach has a very important role in a team. A coach must be able to have the right training program, form of training and playing style for a team. So the style of playing a team is in accordance with the character of each athlete's play. In addition, by having a training program and the right playing style, the vision of playing a team will be clearly seen in an effort to win.

\section{RESEARCH METHODS}

This research was conducted using descriptive research that aims to describe the situation that occurs in an object. According to Arikunto (1996), descriptive research is research that does not intend to test certain hypotheses but only describes what they are about an event or event. Furthermore, Sugiyono (2008) states that descriptive research is one type of research that describes systematically, actual and accurate about the facts of a particular population or tries to describe the phenomenon in detail. This research was conducted in July 2018. This research was carried out at the Garuda basketball club located in the auditorium of Don Bosco High School and the HTT basketball court in Padang.

\section{RESULTS AND DISCUSSION \\ 1. Data of Passing Skill Test for Basketball Athletes of Putra Garuda Padang}

Based on the data of the passing skills test for the basketball athletes of the Padang Garuda, the highest score $=24$ and the lowest score $=16$, the average score $=19,53$ and the standard deviation $=2.20$. For more details on the passing skills test of the Garuda Garuda basketball athlete, the frequency distribution of the Garuda athletes basketball ball passing skills test data can be seen in the table below.

Table 1. Frequency Distribution of Passing Skill Test for Basketball athlete of Putra Garuda Padang.

\begin{tabular}{|c|c|c|c|}
\hline Interval Class & Fa & Category & Fr \% \\
\hline$>23$ & 1 & Very well & $6.67 \%$ \\
\hline $22-23$ & 2 & Well & $13.33 \%$ \\
\hline
\end{tabular}




\begin{tabular}{|c|c|c|c|}
\cline { 3 - 3 } $19-21$ & 7 & Enough & $46.67 \%$ \\
\hline $17-18$ & 4 & Less & $26.67 \%$ \\
\hline$<16$ & 1 & Very, very little & $6.67 \%$ \\
\hline amount & $\mathbf{1 5}$ & & $100 \%$ \\
\hline
\end{tabular}

\section{Data ofBasketballAthlete of Putra Garuda Padang} Training Dribbling Skills

Based on the dribbling skills test data of the Padang Garuda athletes, the highest score $=10.44$ and the lowest score $=14,43$, the average $=12.39$ and the standard deviation $=1.38$. For more details of test data skill dribbling basketballathlete of Garuda Padang. The distributionof skills test data frequency dribbling basketball athlete of Garuda Padang can be seen in the table below.

Table 2. Frequency Distribution of Dribbling Skill Test for Putra Garuda Padang Athletes.

\begin{tabular}{|c|c|c|c|}
\hline Interval Class & Fa & Category & Fr\% \\
\hline$<10,32$ & 0 & Very well & $0.00 \%$ \\
\hline $10,32-11,71$ & 7 & Well & $46.67 \%$ \\
\hline $11.70-13.07$ & 2 & Enough & $13.33 \%$ \\
\hline $13.08-14.45$ & 6 & Less & $40.00 \%$ \\
\hline$>14.46$ & 0 & Very, very little & $0.00 \%$ \\
\hline amount & $\mathbf{1 5}$ & & $100 \%$ \\
\hline
\end{tabular}

\section{Data on the Shooting Skill of Basketball} Athletesof Putra Garuda Padang

Based on the data of the shooting skills test of the Padang basketball athletes, the highest score $=12$ and the lowest score $=7$, the average score $=9,07$ and the standard deviation $=1.49$. For more details dribbling skills test data from Garuda Indonesia basketball athletes, the frequency distribution of the shooting skills for Padang basketball athletes can be seen in the table below

Table 3. Data Frequency Distribution of Shooting Skill Test for BasketballAthletes of Putra Garuda Padang

\begin{tabular}{|c|c|c|c|}
\hline Interval Class & Fa & Category & Fr \% \\
\hline$>12$ & 0 & Very well & $0.00 \%$ \\
\hline $11-12$ & 3 & Well & $20.00 \%$ \\
\hline $9-10$ & 6 & Enough & $40.00 \%$ \\
\hline $7-8$ & 6 & Less & $40.00 \%$ \\
\hline$<7$ & 0 & Very, very little & $0.00 \%$ \\
\hline
\end{tabular}

\section{PassingDribbling and Shooting Skill Test Data for} Garuda Padang Athletes in T-Score

Skills test data results passing, dribbling and shootingbasketballathlete of Garuda Padang who had done then transformed to a value $\mathrm{T}$ - Score. For more details, skill test data passing, dribbling and shooting basketball athlete of Putra Garuda Padang who has transformed into shape $\mathrm{T}$ - frequency distribution of test data skills passingdribbling and shooting athlete basketball eagle son Padangdapat seen in the table below. 
Table 4. Data Frequency Distribution of PassingDribbling and Shooting Skill Tests for Basketball Athletes of Putra Garuda Padang

\begin{tabular}{|c|c|c|c|c|}
\hline No & $\begin{array}{c}\text { Number of T- } \\
\text { Scores }\end{array}$ & Fa & Category & Fr \% \\
\hline 1 & $>222$ & 0 & Very well & $0.00 \%$ \\
\hline 2 & $193-221$ & 0 & Well & $0.00 \%$ \\
\hline 3 & $165-192$ & 2 & Enough & $13.33 \%$ \\
\hline 4 & $136-164$ & 11 & Is & $73.33 \%$ \\
\hline 5 & $107-135$ & 2 & Less & $13.33 \%$ \\
\hline 6 & $79-106$ & 0 & Very, very little & $0.00 \%$ \\
\hline 7 & $<78$ & 0 & Bad & $0.00 \%$ \\
\hline & amount & $\mathbf{1 5}$ & & $\mathbf{1 0 0 \%}$ \\
\hline
\end{tabular}

\section{Passing Skill of the Basketball Athlete of Putra Garuda Padang}

Passing is one way to create points in basketball. This is because without the passing there is no bait to create points in playing basketball, so the passing must be done of course to the target or the target passing that has been determined. Based on the results of research that has been done on Padang Garuda Youth basketball athletes revealed that the passing skills possessed by most Padang Garuda Youth basketball athletes are only in the moderate category with the percentage of athletes as much as $46.67 \%$.

In passing a basketball player must pay attention to several components so that the passing is carried out right on the target that has been determined with the right timing. According to Wissel ( 2000: 2 ), some passing components that must be considered by each player are as follows :

a. Speed. The passing ball must be sharp, fast, not too hard and not too slow.

b. Target. Every passing must be precise/accurate on a specific target.

c. Timing. The ball must reach the recipient at the right time, but not before or after.

d. The trick. Players who pass must try to use tricks to fool the defender. Usually, a defender is fooled when we use eye tricks.

e. Communication. Communication between players is needed to reduce the risk of turnover (eye, voice, signal communication).

Based on the opinion above, we can conclude that the key in passing is the ball must arrive at the target or target that has been determined with the right speed and time. Judging from the passing skills possessed by the Padang Garuda athletes, there is a need to practice to improve passing skills. So that failure during an attack in a match can be minimized, thus the possibility of creating more points in a match will be possible.

\section{Skills Dribbling of Basketball Athlete of Putra Garuda Padang}

Based on the research that has been done, it was revealed that of the 15 athletes of Padang Garuda basketball athletes, only $46.67 \%$ had good dribbling skills, while $53.33 \%$ were in the sufficient and lacking categories. This means that out of the 15 athletes only 7 people have good dribbling skills while the other 8 people have enough and less dribbling skills.

Dribbling is not a different part ofbasketball games and it is important for athletes to play individually or in teams. According to Fardi (1999 ),Dribbling is a form of movement to bring the ball which is authorized by regulations ". This skill is also a basic skill that must be mastered by a basketball player in order to get past an opponent when mastering the ball. Next Soedik Oe n (1992 ) suggested how to do a good dribbling, among others:

a. Hold the ball with both hands in a relaxed manner, right hand on the ball left below where the ball is located.

b. Stand at will with your left foot slightly forward and right foot.

c. Lean forward from the waist.

d. The bounce of the ball is done with the right hand.

e. Almost entirely arm movements.

f. The bounce of the ball is done with the fingers supported by the wrist (not hit with the palm of the hand)

g. Menjina $\mathrm{k}$ kan ball with a bit following the movement of the ball up briefly with the fingers and wrists then just be reflected back. 
h. After having a good rhythm of reflection with a standing attitude then start while moving forward or backward.

i. Start by not seeing the ball, and speed it up.

Based on the above description, it can be concluded that the dribbling skills possessed by the Padang Garuda athletes need to be improved. This is intended so that athletes can more easily pass the opponent when controlling the ball and the possibility to create more points in a match will be done.

\section{Shooting Skill of Basketball athlete of Putra Garuda Padang}

From the results of the shooting skills test for Padang basketball athletes, it can be seen that from 15 athletes only $3(20 \%)$ have good shooting skills and 12 others $(80 \%)$ have sufficient and lacking shooting abilities. The results of this test have certainly been able to illustrate the ability of the Padang Garuda Youth basketball team in scoring points in a match. Shooting is one of the basic techniques of basketball game that must be mastered by every athlete. This shooting is a way or effort to create points in a match. According to Kosasih (2008),shooting is the basic skill of basketball which is best known and favored because every player has the instinct to score points. Furthermore according to Sodikoen, (1991) "shooting is the final target of every play and its success in making shots".

Based on the description above it can be concluded that to win in a match requires an effort to create as many points as possible to the opponent's ring, this can be done by shooting with a good level of success. In reality, the shooting skills possessed by the Padang Garuda athletes are still not in line with the desired expectations. This can be seen from the results of tests conducted on the Garuda athletes in Padang. Therefore, good training is needed to improve the shooting skills of the Padang Garuda athletes.

\section{Skills Passing, Dribbling and Shooting Basketball} Athlete ofPutra Garuda Padang

Basketball is a sport that contains elements of complex and attractive movements. This means that the movements needed to play basketball are a combination of mutually supporting elements of the movement. For example, before throwing a ball, the athlete must first know how to hold the ball. To be able to play basketball with both the individual elements of the movement should be studied one by one, and the subsequent need for coordination between elements of movement with each other.

The player's ability to perform these movements is very dependent on the mastery of the basic techniques that support the game, with good and correct basic techniques, the efficiency and effectiveness of the motion will be achieved and will be able to easily combine basic techniques in situations which supports the game without experiencing significant difficulties.

Based on the results of tests that have been performed on each of the basic techniques of the game of basketball, it can be concluded that the skills of the basic techniques of the game basketball athlete basketball son Garuda Padang is still not in accordance with what is expected in this case can be viewed on research data obtained, overall the basic technical skills of the basketball game of the basketball athlete in Padang is in the medium category. This is certainly not optimal to achieve the achievements of the Padang Garuda basketball club, therefore it must be improved with an increase in the training process.

\section{CONCLUSIONS AND SUGGESTIONS}

Based on the results of research and discussion that has been done in the previous chapter, the conclusion in this study is the passing ability of the basketball athletes of Padang athletes is in the sufficient category with the percentage of athletes as much as $46.67 \%$ (7 people), which are in good once $6.67 \%$ (1 person), in the good category $13.33 \%$ (2 people) and $33.33 \%$ others are in the category of less and less. The dribbling abilities possessed by the athletes of the Padang Garuda athletes are in the average enough and less categories with a percentage of $53.33 \%$ ( 8 people), while others are in the good category with a percentage of $46.67 \%$ ( 7 people). The shooting capabilities possessed by the Padang Garuda men's basketball athletes are on average enough and less categories with a percentage of $80 \%$ (12 people), while others are in the good category with a percentage of $20 \%$ (3 people).

\section{REFERENCES}

[1] Arikunto, Suharsimi. 1991. Dasar-Dasar Evaluasi Pendidikan. Jakarta: Bumi Aksara.

[2] Fardi, Adnan. 1999. Bolabasket Dasar. Fakultas Ilmu Keolahragaan: Universitas Negeri Padang.

[3] Kosasih, Danny. 2008. Fundamental Basketball: First Step To Win. Semarang: Karangturi Media.

[4] Soedikoen, Imam. 1992. Olahraga Pilihan Bolabasket. Padang: FPOK IKIP Padang.

[5] Sugiyono. 2008. Metode Penelitian Kuantitatif, Kualitatif dan R \& D. Bandung: CV AlFABETA.

[6] Wissel, Hal. Bolabasket.Dilengkapi Dengan Program Pemahiran Tekhnik Dan Taktik.Terjemahan oleh Bagus Pribadi. 2000. Jakarta: PT Raja Grafindo Persada. 